\title{
Bacillus macyae sp. nov., an arsenate-respiring bacterium isolated from an Australian gold mine
}

Correspondence

Joanne M. Santini

j.santini@latrobe.edu.au

\author{
Joanne M. Santini, Illo C. A. Streimann and Rachel N. vanden Hoven \\ Department of Microbiology, La Trobe University, 3086, Victoria, Australia
}

\begin{abstract}
A strictly anaerobic arsenate-respiring bacterium isolated from a gold mine in Bendigo, Victoria, Australia, belonging to the genus Bacillus is described. Cells are Gram-positive, motile rods capable of respiring with arsenate and nitrate as terminal electron acceptors using a variety of substrates, including acetate as the electron donor. Reduction of arsenate to arsenite is catalysed by a membrane-bound arsenate reductase that displays activity over a broad $\mathrm{pH}$ range. Synthesis of the enzyme is regulated; maximal activity is obtained when the organism is grown with arsenate as the terminal electron acceptor and no activity is detectable when it is grown with nitrate. Mass of the catalytic subunit was determined to be approximately $87 \mathrm{kDa}$ based on ingel activity stains. The closest phylogenetic relative, based on 16S rRNA gene sequence analysis, is Bacillus arseniciselenatis, but DNA-DNA hybridization experiments clearly show that strain $\mathrm{JMM}-4^{\top}$ represents a novel Bacillus species, for which the name Bacillus macyae sp. nov. is proposed. The type strain is $\mathrm{JMM}-4^{\top}\left(=\mathrm{DSM} 16346^{\top}=\mathrm{JCM} 12340^{\top}\right)$.
\end{abstract}

The arsenic oxyanion arsenate $[\mathrm{As}(\mathrm{V})]$ can be used by prokaryotes in anaerobic respiration as a terminal electron acceptor. The arsenate is reduced to arsenite coupled with the oxidation of several electron donors, thereby generating energy for growth. Eighteen species of arsenate-respiring prokaryotes have been isolated from diverse environments that are physiologically and phylogenetically unique (Oremland \& Stolz, 2003). These organisms range from mesophiles to extremophiles, and can be adapted to extremes of temperature, $\mathrm{pH}$ and salinity.

The mechanism of arsenate respiration has only been studied in three of these organisms, namely Chrysiogenes arsenatis (Krafft \& Macy, 1998), Bacillus selenitireducens (Afkar et al., 2003) and Shewanella sp. strain ANA-3 (Saltikov \& Newman, 2003); the arsenate reductases (Arr) of $C$. arsenatis and B. selenitireducens have been purified and characterized and the genes encoding the Arr of Shewanella sp. strain ANA-3 have been cloned and sequenced. The three enzymes share similarities, suggesting that the differences between them have occurred by divergent evolution.

A Gram-positive, strictly anaerobic, arsenate-respiring bacterium was isolated from an arsenic-contaminated environment in Bendigo, Victoria, Australia (Santini et al., 2002).

Published online ahead of print on 28 June 2004 as DOI 10.1099/ ijs.0.63059-0.

Abbreviation: Arr, arsenate reductase.

The GenBank/EMBL/DDBJ accession number for the 16S rRNA gene sequence of $\mathrm{JMM}-4^{\top}$ is $A Y 032601$.
This strain (JMM-4 $\left.{ }^{\mathrm{T}}\right)$ can couple the reduction of arsenate to arsenite with the oxidation of lactate to $\mathrm{CO}_{2}$ via the intermediate acetate. Based on 16S rRNA gene sequence analysis, JMM- $4^{\mathrm{T}}$ falls within the low-G $+\mathrm{C}$ Gram-positive, aerobic, spore-forming bacilli cluster and is most closely related to the haloalkalophilic arsenate/selenate-respiring bacterium Bacillus arseniciselenatis (Switzer Blum et al., 1998). Here we determine, based on physiological, phylogenetic and molecular analyses, that JMM $-4^{\mathrm{T}}$ represents a novel Bacillus species, for which the name Bacillus macyae sp. nov. is proposed. We also provide preliminary data on the arsenate reductase of this organism.

JMM-4 $4^{\mathrm{T}}$ was grown as described by Santini et al. (2002) except that yeast extract $(0.08 \%)$ was used instead of vitamins for all experiments. Sodium lactate $(10 \mathrm{mM})$ was used as the electron donor and sodium arsenate $(5 \mathrm{mM})$ or sodium nitrate $(5 \mathrm{mM})$ as the terminal electron acceptors. For enzyme studies, JMM- $4^{\mathrm{T}}$ was grown in 2 litre batch cultures until late-exponential phase. B. arseniciselenatis (ATCC $700614^{\mathrm{T}}$ ) was grown as described by Switzer Blum et al. (1998) but in the absence of a reducing agent and with $\mathrm{NaCl}\left(40 \mathrm{~g} \mathrm{l}^{-1}\right)$ and $0 \cdot 1 \%$ yeast extract. Sodium lactate $(10 \mathrm{mM})$ was used as the electron donor and sodium nitrate $(10 \mathrm{mM})$ as the terminal electron acceptor.

For genomic DNA isolations, JMM- $4^{\mathrm{T}}$ and $B$. arseniciselenatis were grown in 2 litre batches containing $5 \mathrm{mM}$ arsenate, $10 \mathrm{mM}$ lactate and $0 \cdot 1 \%$ yeast extract, and $10 \mathrm{mM}$ nitrate, $10 \mathrm{mM}$ lactate and $0 \cdot 1 \%$ yeast extract, respectively, until mid- to late-exponential phase. Cells were harvested by centrifugation for $20 \mathrm{~min}$ at $21000 \mathrm{~g}\left(4^{\circ} \mathrm{C}\right)$. JMM- $4^{\mathrm{T}}$ genomic DNA was isolated using the Wizard SV Genomic 
DNA Purification System (Promega). B. arseniciselenatis genomic DNA was isolated by the DSMZ (Deutsche Sammlung von Mikroorganismen und Zellkulturen, Braunschweig, Germany). B. arseniciselenatis cells were disrupted by French press and the DNA purified by hydroxyapatite chromatography as described by Cashion et al. (1977). DNA base composition of JMM-4 ${ }^{\mathrm{T}}$ was determined by HPLC again at the DSMZ. DNA-DNA hybridization of strain JMM- $4^{\mathrm{T}}$ and B. arseniciselenatis was carried out as described by De Ley et al. (1970) with the modifications described by Huss et al. (1983) and Escara \& Hutton (1980) in $2 \times$ SSC at $62^{\circ} \mathrm{C}$ by the DSMZ.

For biochemical studies, JMM-4 ${ }^{\mathrm{T}}$ cells were harvested by centrifugation for $20 \mathrm{~min}$ at $21000 \mathrm{~g}\left(4^{\circ} \mathrm{C}\right)$, suspended in $50 \mathrm{mM}$ Tris/ $\mathrm{HCl}(\mathrm{pH} 8 \cdot 5)$ and the cells disrupted by two passages through a French press $\left(1 \cdot 4 \times 10^{9} \mathrm{~Pa}\right)$. Unbroken cells were removed by centrifugation at $17000 \mathrm{~g}\left(4^{\circ} \mathrm{C}\right)$. The soluble and membrane fractions were separated by ultracentrifugation for $1 \mathrm{~h}$ at $100000 \mathrm{~g}\left(4^{\circ} \mathrm{C}\right)$. The pellet (i.e. membranes) was suspended in $50 \mathrm{mM}$ Tris/ $\mathrm{HCl}(\mathrm{pH} 8 \cdot 5)$ $\left(0{ }^{\circ} \mathrm{C}\right)$; the volume used was identical to that of the supernatant (i.e. the soluble fraction).

Arsenate and nitrate reductase activity was determined using anaerobic assays $\left(25^{\circ} \mathrm{C}\right)$ in cuvettes $(1 \mathrm{~cm})$ closed with butyl-rubber stoppers. Enzyme activity was determined using a Cary $1 \mathrm{E}$ spectrophotometer (Varian) by monitoring oxidation of the artificial electron donors, reduced benzyl $(1 \mathrm{mM})$ or methyl viologen $(1 \mathrm{mM})$ at $546 \mathrm{~nm}$ or $540 \mathrm{~nm}$, respectively, using arsenate $(10 \mathrm{mM})$ or nitrate $(10 \mathrm{mM})$ as the electron acceptors ( $\varepsilon$ of reduced benzyl and methyl viologen is $19 \cdot 5$ and $4.95 \mathrm{~cm}^{-1} \mathrm{mM}^{-1}$, respectively). The artificial electron donors were reduced chemically with sodium hydrosulfite $\left(0 \cdot 15 \mathrm{mg} \mathrm{ml}^{-1}\right)$. The reaction was started by addition of the electron acceptor. One unit (U) of activity corresponded to the reduction of $1 \mu \mathrm{mol}$ arsenate or nitrate per minute. To determine the optimum buffer and $\mathrm{pH}$ for the enzyme, Arr activity was tested in $50 \mathrm{mM}$ MES (pH 5·5, 6 and 6.5), MOPS (pH 6.5, 7 and 7·5), Tris/ $\mathrm{HCl}(\mathrm{pH} 7 \cdot 5,8$ and $8 \cdot 5)$ and CHES (pH 9). All subsequent Arr assays were done in $50 \mathrm{mM}$ Tris/ $\mathrm{HCl}(\mathrm{pH} \mathrm{8} \cdot 5)$. All enzyme assays were performed at least in duplicate and on two separate occasions. To identify the Arr, ingel activity stains were performed as described by Bluemle \& Zumft (1991) except that the nitrate was replaced with arsenate.

Colonies observed in Hungate roll tubes were circular and white. JMM- $4^{\mathrm{T}}$ is a Gram-positive, motile (four to six peritrichous flagella), spore-forming, rod-shaped bacterium that grows singly. Spores are terminal and ellipsoidal and swelling of the sporangia is not observed. JMM $-4^{\mathrm{T}}$ was found to be catalase-positive and oxidase-negative. JMM-4 ${ }^{\mathrm{T}}$ can grow with either arsenate or nitrate as terminal electron acceptors; the arsenate is reduced to arsenite and nitrate to nitrite (Santini et al., 2002) (Table 1). The electron acceptors oxygen, arsenite, $\mathrm{Fe}(\mathrm{III})$, nitrite, selenate, sulfate, thiosulfate (Santini et al., 2002) and fumarate did not support growth (Table 1). Comparisons with its closest
Table 1. Comparison of strain $\mathrm{JMM}-4^{\top}$ with $B$. arseniciselenatis strain $\mathrm{E} 1 \mathrm{H}^{\mathrm{T}}$

Both JMM $-4^{\mathrm{T}}$ and B. arseniciselenatis $\mathrm{E} 1 \mathrm{H}^{\mathrm{T}}$ produce spores. Both use arsenate and nitrate as terminal electron acceptors, and use lactate and malate as electron donors. Neither uses nitrite, selenite, oxygen, sulfate and thiosulfate as electron acceptors, nor formate, dextrose, galactose and glycine as electron donors. JMM-4 ${ }^{\mathrm{T}}$ was grown under the same conditions for all results presented in this table. ND, Not determined.

\begin{tabular}{|c|c|c|}
\hline Characteristic & Strain JMM-4 ${ }^{\mathrm{T}_{\star}}$ & Strain $\mathrm{E} \mathrm{H}^{\mathrm{T}}{ }_{\dagger}$ \\
\hline Cell dimensions $(\mu \mathrm{m})$ & $0 \cdot 6 \times 2 \cdot 5-3$ & $1 \times 3$ \\
\hline Motility & + & $+\ddagger$ \\
\hline $\begin{array}{l}\text { Temperature range for } \\
\text { growth }\left({ }^{\circ} \mathrm{C}\right) \\
\text { pH for growth: }\end{array}$ & $28-37 \ddagger$ & ND \\
\hline Range & $7-8 \cdot 4$ & $7-10 \cdot 2$ \\
\hline Optimum & $7 \cdot 8$ & $9 \cdot 8$ \\
\hline \multicolumn{3}{|l|}{$\mathrm{NaCl}$ for growth: } \\
\hline Range & $1 \cdot 2-30$ & $20-120$ \\
\hline Optimum & $1 \cdot 2$ & 60 \\
\hline \multicolumn{3}{|l|}{ Electron acceptors: } \\
\hline Arsenite & - & ND \\
\hline Selenate & - & + \\
\hline Fumarate & 一キ & + \\
\hline Iron(III) & - & + \\
\hline \multicolumn{3}{|l|}{ Electron donors: } \\
\hline Acetate & + & - \\
\hline Pyruvate & + & - \\
\hline Succinate & + & - \\
\hline Citrate & - & + \\
\hline Glutamate & + & - \\
\hline Hydrogen + acetate & + & - \\
\hline Starch & - & + \\
\hline Fructose & - & $+\S$ \\
\hline Xylose & - & ND \\
\hline
\end{tabular}

${ }^{\star}$ Results obtained from Santini et al. (2002) unless specified otherwise.

$\nmid$ Results obtained from Switzer Blum et al. (1998) unless specified otherwise.

$\ddagger$ Results obtained in this study.

$\S$ Growth was also obtained in the absence of an electron acceptor.

phylogenetic relative, based on 16S rRNA gene sequence analysis, the haloalkalophile B. arseniciselenatis strain $\mathrm{E} 1 \mathrm{H}^{\mathrm{T}}$ $(97 \cdot 3 \%$ similarity), are given in Table 1 . Electron donors used by JMM- $4^{\mathrm{T}}$ are also given in Table 1 . JMM- $4^{\mathrm{T}}$ grew just as well at $37^{\circ} \mathrm{C}$ as it did at $28^{\circ} \mathrm{C}$ but it did not grow at 4 or $42^{\circ} \mathrm{C}$.

Phylogenetic analysis of the 16S rRNA gene sequence (1512 bp) of JMM-4 ${ }^{\mathrm{T}}$ showed that it fell within the lowG + C, Gram-positive, aerobic, spore-forming bacilli cluster (Santini et al., 2002). The nearest phylogenetic relatives of $\mathrm{JMM}-4^{\mathrm{T}}$ were the alkalophilic Bacillus species, including 
B. arseniciselenatis $(97 \cdot 3 \%)$, Bacillus pseudofirmus $(95 \cdot 1 \%)$ (GenBank/EMBL/DDBJ accession no. X76439), Bacillus pseudalcaliphilus (94.4\%) (X76449), Bacillus alcalophilus $(93.9 \%)$ (X60603) and B. selenitireducens (92.3\%) (AF064704) (Santini et al., 2002). Based on the fact that the 16S RNA gene sequence of JMM- $4^{\mathrm{T}}$ was more than $97 \%$ similar to that of $B$. arseniciselenatis, both DNA-DNA hybridization values and $\mathrm{G}+\mathrm{C}$ content were determined (Stackebrandt \& Goebel, 1994; Stackebrandt et al., 2002).

DNA-DNA hybridization between JMM- $4^{\mathrm{T}}$ and B. arseniciselenatis was found to be $30 \cdot 4 \%$, below the recommended value delimiting different species (Wayne et al., 1987; Stackebrandt et al., 2002). The DNA G + C content of strain $\mathrm{JMM}-4^{\mathrm{T}}$ was $37 \mathrm{~mol} \%$ compared with $40 \mathrm{~mol} \%$ for $B$. arseniciselenatis (Switzer Blum et al., 1998).

Preliminary experiments of the Arr of strain JMM-4 $4^{\mathrm{T}}$ showed activity in total cell extracts to be stable over a broad $\mathrm{pH}$ range. Optimal activity occurred with methyl viologen as the artificial electron donor in Tris/ $\mathrm{HCl}$ $(\mathrm{pH} 8)\left(2 \cdot 3 \pm 0 \cdot 15 \mathrm{U} \mathrm{mg}^{-1}\right)$, Tris/HCl $(\mathrm{pH} 8 \cdot 5)(2 \cdot 15 \pm$ $\left.0 \cdot 35 \mathrm{U} \mathrm{mg}^{-1}\right)$ and CHES (pH 9) $\left(2 \cdot 3 \pm 0 \cdot 2 \mathrm{U} \mathrm{mg}^{-1}\right)$. Arr activity was still detected in MES ( $\mathrm{pH} 5 \cdot 5$ ) buffer, where the enzyme displayed $33 \%$ maximal activity. Arr activity with benzyl viologen as the artificial electron donor was found to be $3 \cdot 5$-fold less than $\left[0 \cdot 595 \pm 0.005 \mathrm{U} \mathrm{mg}^{-1}\right.$ in Tris/ $\mathrm{HCl}(\mathrm{pH} \mathrm{8.5)]} \mathrm{with} \mathrm{methyl} \mathrm{viologen.} \mathrm{Tris/HCl}$ $(\mathrm{pH} 8.5)$ and methyl viologen were used for all further experiments. The Arr of B. selenitireducens also displays a broad $\mathrm{pH}$ range $(\mathrm{pH} 6-11)$, with optimum activity at $\mathrm{pH} 9 \cdot 5$, which is similar to the optimum $\mathrm{pH}$ for growth of the organism (Afkar et al., 2003). The purified B. selenitireducens Arr displays a maximum activity of $2.5 \mathrm{U}$ $\mathrm{mg}^{-1}$, which is similar to the specific activity of the Arr of strain JMM- $4^{\mathrm{T}}$ in total cell extracts. These results suggest either (1) that JMM-4 $4^{\mathrm{T}}$ expresses more Arr than $B$. selenitireducens or (2) that the Arr of JMM- $4^{\mathrm{T}}$ displays a higher enzyme turnover.

The effect of different growth conditions on Arr activity was determined. These experiments were performed to determine whether the enzyme is constitutively expressed or whether its synthesis is regulated. When $\mathrm{JMM}-4^{\mathrm{T}}$ was grown with only nitrate as the terminal electron acceptor no Arr activity was detected $\left(<0 \cdot 01 \mathrm{U} \mathrm{mg}^{-1}\right)$, whereas nitrate reductase activity was detected $\left(7 \cdot 7 \pm 0 \cdot 3 \mathrm{U} \mathrm{mg}^{-1}\right)$. This suggests that arsenate is required for induction of enzyme synthesis. This was also found to be the case for the Arr of C. arsenatis (Krafft \& Macy, 1998). When $\mathrm{JMM}-4^{\mathrm{T}}$ was grown with both nitrate and arsenate, Arr activity decreased by about 10 -fold as compared with activity in cell extracts from cells grown with only arsenate as the electron acceptor $(0 \cdot 25 \pm 0 \cdot 0$ versus $\left.2 \cdot 15 \pm 0 \cdot 35 \mathrm{U} \mathrm{mg}^{-1}\right)$. Nitrate reductase activity was slightly higher $\left(8 \cdot 5 \pm 0 \cdot 0 \mathrm{U} \mathrm{mg}^{-1}\right)$ in cell extracts grown with nitrate/arsenate. No nitrate reductase activity was detected in cell extracts grown with arsenate $\left(<0 \cdot 01 \mathrm{U} \mathrm{mg}^{-1}\right)$. These results contrast with those for the C. arsenatis Arr, in which the activity remains the same when the organism is grown with either arsenate or arsenate/nitrate (Krafft \& Macy, 1998). These preliminary results suggest that arsenate and nitrate respiration may be co-regulated.

Strain JMM-4 $4^{\mathrm{T}}$ Arr was found to be membrane-bound; $81 \cdot 6 \%$ of the activity was associated with the membranes and $18.4 \%$ in the soluble fraction. These results suggest that the Arr is not an integral membrane protein as a significant amount of activity was found in the soluble fraction. The Arr of C. arsenatis is periplasmic (Krafft \& Macy, 1998), whereas the Arr of B. selenitireducens is membrane-bound (Afkar et al., 2003).

Arr activity was monitored using SDS-polyacrylamide gels (Fig. 1). Reductase activity was detected in total cell and membrane fractions. The estimated size of the band displaying activity was $87 \mathrm{kDa}$. This result corresponds well with the molecular masses of the catalytic subunits (ArrA) of the arsenate reductases of C. arsenatis ( $87 \mathrm{kDa})$ and B. selenitireducens $(110 \mathrm{kDa})$.

\section{Description of Bacillus macyae sp. nov.}

Bacillus macyae (ma.cy'ae. N.L. fem. n. macyae of Macy, named after the late Professor Joan M. Macy, Chair of

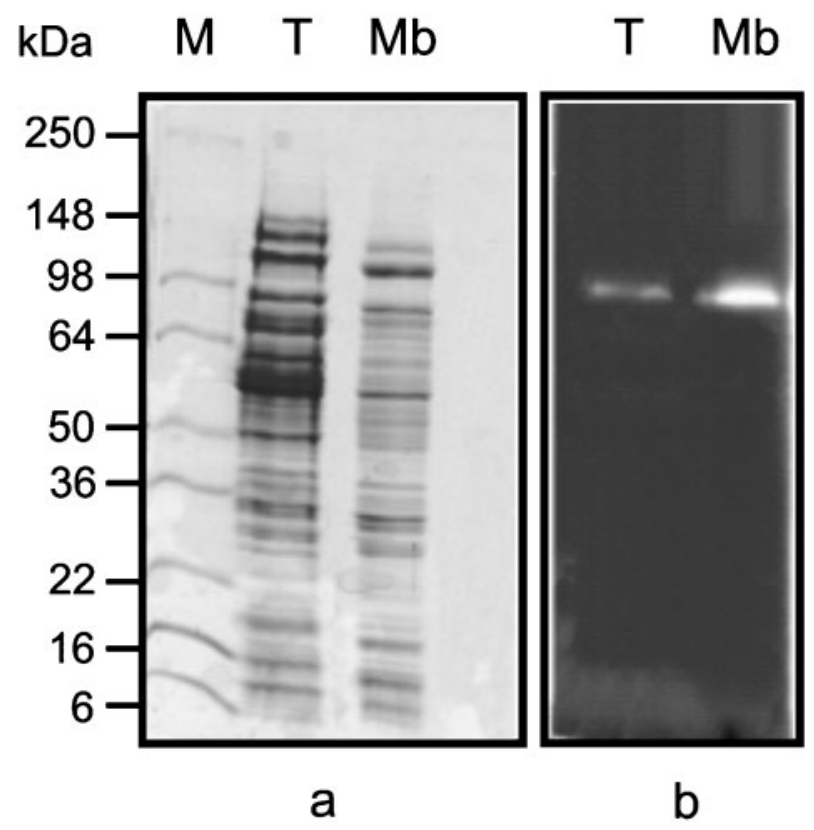

Fig. 1. SDS-polyacrylamide gradient (6-13.5\%) gel and Arr ingel activity stain of the arsenate reductase (Arr) of JMM- $4^{\top}$. (a) Coomassie blue-stained gel. Molecular mass markers (M): myosin $(250 \mathrm{kDa})$, phosphorylase $\mathrm{B}(148 \mathrm{kDa})$, bovine serum albumin $(98 \mathrm{kDa})$, glutamic dehydrogenase $(64 \mathrm{kDa})$, alcohol dehydrogenase (50 kDa), carbonic anhydrase (36 kDa), myoglobin red $(22 \mathrm{kDa})$, lysozyme $(16 \mathrm{kDa})$, aprotinin $(6 \mathrm{kDa}) ; \mathrm{JMM}-4^{\top}$ total cell extract $(\mathrm{T})$; and membrane $(\mathrm{Mb})$ fractions. (b) Ingel activity stain of Arr of $\mathrm{JMM}-4^{\top}$. 
Microbiology, La Trobe University, in tribute to her research in the area of environmental microbiology).

Cells are Gram-positive, motile rods $(2 \cdot 5-3 \mu \mathrm{m}$ long and $0.6 \mu \mathrm{m}$ wide) and produce subterminally located ellipsoidal spores. Spores do not cause swelling of sporangia. Colonies are round and white. Catalase reaction is positive and oxidase is negative. Strict anaerobe that respires with arsenate and nitrate as terminal electron acceptors. Arsenate is reduced to arsenite and nitrate to nitrite. The electron donors used for anaerobic respiration are acetate, lactate, pyruvate, succinate, malate, glutamate and hydrogen (with acetate as carbon source). Growth occurs at $28-37^{\circ} \mathrm{C}$, $\mathrm{pH} 7-8 \cdot 4$ and $0 \cdot 12-3 \% \mathrm{NaCl}$. The DNA G $+\mathrm{C}$ content is $37 \mathrm{~mol} \%$.

The type strain, JMM- $4^{\mathrm{T}}\left(=\mathrm{DSM} 16346^{\mathrm{T}}=\mathrm{JCM} 12340^{\mathrm{T}}\right)$, was isolated from arsenic-contaminated mud from a gold mine in Bendigo, Victoria, Australia.

\section{Acknowledgements}

This work was supported by an Australian Research Council (ARC) Grant (DP0209802) to J.M.S. J.M.S. is a recipient of an ARC Australian Postdoctoral fellowship. R.N.v.H. and I.C.A.S. are recipients of an Australian Postgraduate Award and La Trobe University Postgraduate Award, respectively. We would like to thank R. S. Oremland and J. Switzer Blum for providing B. arseniciselenatis and B. J. Tindall for assistance with nomenclature.

\section{References}

Afkar, E., Lisak, J., Saltikov, C., Basu, P., Oremland, R. S. \& Stolz, J. F. (2003). The respiratory arsenate reductase from Bacillus selenitireducens strain MLS10. FEMS Microbiol Lett 226, 107-112.

Bluemle, S. \& Zumft, W. G. (1991). Respiratory nitrate reductase from denitrifying Pseudomonas stutzeri, purification, properties and target of proteolysis. Biochim Biophys Acta 1057, 102-108.
Cashion, P., Hodler-Franklin, M. A., McCully, J. \& Franklin, M. (1977). A rapid method for base ratio determination of bacterial DNA. Anal Biochem 81, 461-466.

De Ley, J., Cattoir, H. \& Reynaerts, A. (1970). The quantitative measurement of DNA hybridization from renaturation rates. Eur J Biochem 12, 133-142.

Escara, J. F. \& Hutton, J. R. (1980). Thermal stability and renaturation of DNA in dimethyl sulfoxide solutions: acceleration of renaturation rate. Biopolymers 19, 1315-1327.

Huss, V. A. R., Festel, H. \& Schleifer, K. H. (1983). Studies on the spectrophotometric determination of DNA hybridization from renaturation rates. Syst Appl Microbiol 4, 184-192.

Krafft, T. \& Macy, J. M. (1998). Purification and characterization of the respiratory arsenate reductase of Chrysiogenes arsenatis. Eur $J$ Biochem 255, 647-653.

Oremland, R. S. \& Stolz, J. F. (2003). The ecology of arsenic. Science 300, 939-944.

Saltikov, C. W. \& Newman, D. K. (2003). Genetic identification of a respiratory arsenate reductase. Proc Natl Acad Sci U S A 100, 10983-10988.

Santini, J. M., Stolz, J. F. \& Macy, J. M. (2002). Isolation of a new arsenate-respiring bacterium - physiological and phylogenetic studies. Geomicrobiol J 19, 41-52.

Stackebrandt, E. \& Goebel, B. M. (1994). Taxonomic note: a place for DNA-DNA reassociation and 16S rRNA sequence analysis in the present species definition in bacteriology. Int J Syst Bacteriol 44, 846-849.

Stackebrandt, E., Frederiksen, W., Garrity, G. M. \& 10 other authors (2002). Report of the ad hoc committee for the re-evaluation of the species definition in bacteriology. Int J Syst Evol Microbiol 52, 1043-1047.

Switzer Blum, J., Burns Bindi, A., Buzzelli, J., Stolz, J. F. \& Oremland, R. S. (1998). Bacillus arsenicoselenatis, sp. nov., and Bacillus selenitireducens, sp. nov.: two haloalkaliphiles from Mono Lake, California that respire oxyanions of selenium and arsenic. Arch Microbiol 171, 19-30.

Wayne, L. G., Brenner, D. J., Colwell, R. R. \& 9 other authors (1987). International Committee on Systematic Bacteriology. Report of the ad hoc committee on reconciliation of approaches to bacterial systematics. Int J Syst Bacteriol 37, 463-464. 